\title{
Linseed (Linum usitatissimum L.) sowing dates, genotypes influence on growth, yield attributes and yield
}

\author{
B.S. ROKADE, K.T. MADANE, J.D. JADHAV* AND P.S. KAMBLE \\ Zonal Agricultural Research Station, SOLAPUR (M.S.) INDIA \\ (Email : slp.aicrpam@gmail.com; aicrpam@gmail.com)
}

\begin{abstract}
The experiment was laid out in Split Plot Design with three replications, with eighteen treatment combinations of date of sowing $\mathrm{D}_{1}-7^{\text {th }}$ October (MW 40), $\mathrm{D}_{2}-14^{\text {th }}$ October (MW 41), $\mathrm{D}_{3}-20^{\text {th }}$ October (MW 42), $\mathrm{D}_{4}-25^{\text {th }}$ October (MW 43), $\mathrm{D}_{5}-30^{\text {th }}$ October (MW 44) and $\mathrm{D}_{6}-5^{\text {th }}$ November (MW 45) as main plot treatments, and three cultivars ( $\mathrm{V}_{1}-$ Kiran, $\mathrm{V}_{2}$ - Garima and $\mathrm{V}_{3}-\mathrm{RLC}$ 4) as sub plot treatments. The gross and net plot size of experimental unit was $6.4 \mathrm{~m} \times 3.6 \mathrm{~m}$ and $5.4 \mathrm{~m} \times 2.4 \mathrm{~m}$, respectively with a row spacing of $30 \mathrm{~cm}$ and plant spacing as $10 \mathrm{~cm}$. All recommended agronomical practices were adopted as per schedule. First date $\left(D_{1}\right)$ and second date $\left(D_{2}\right)$ crop sown in MW 40 and MW 41 recorded significantly higher leaf area index than other dates of sowing. The various growth characters like, plant height, spread of plant were higher in second $\left(D_{2}\right)$ date than other dates of sowing. Mean number of branches per plant and dry matter accumulation was found significantly superior in first $\left(D_{1}\right)$. $D_{1}$ which required less number of days for 50 per cent flowering and more days for maturity. The various yield attributing characters viz., number of capsules plant ${ }^{-1}$, weight of capsules plant ${ }^{-1}$, number of seeds capsule ${ }^{-1}$, seed weight plant $^{-1}$ and thousand seed weight were found higher in first date of sowing. $\mathrm{D}_{1}$ recorded significantly higher seed yield, straw yield, biological yield and harvest index than other treatments. The various growth characters viz., number of branches plant ${ }^{-1}$, spread of plant, total dry matter accumulation were substantially more in cv. GARIMA except plant height, which was recorded more in cv. RLC-4. Number of days required to 50 per cent flowering were also lesser in cv. GARIMA. The number of days required for physiological maturity were more in cv. KIRAN. Remarkably, the various yield attributes like mean number of capsule plant ${ }^{-1}$, weight of capsules, mean number of seeds capsule ${ }^{-1}$, seed weight plant ${ }^{-1}$, weight of straw plant ${ }^{-1}$ and thousand seed weight were higher in cv. GARIMA over other cultivars. Among the cultivars, Garima recorded higher seed yield, straw yield, and biological yield as well at harvest index.
\end{abstract}

Key Words : Genotypes, Influence, Growth, Yield atributes

View Point Article : Rokade, B.S., Madane, K.T., Jadhav, J.D. and Kambale, P.S. (2015). Linseed (Linum usitatissimum L.) sowing dates, genotypes influence on growth, yield attributes and yield. Internat. J. agric. Sci., 11 (2) : 248-256.

Article History : Received : 29.01.2015; Revised : 11.05.2015; Accepted : 21.05.2015

\footnotetext{
* Author for correspondence
} 